Journal of Ocean Engineering and Technology 26(6), 39-45, December, 2012 http://dx.doi.org/10.5574/KSOE.2012.26.6.039

\author{
수중로봇용 덕트 추진기의 설계 및 성능해석 \\ 김경진** 이두형* • 박원규* • 박한일** \\ *부산대학교 기계공학부 \\ **한국해양대학교 해양공학과
}

\title{
Design and Performance Analysis of Ducted Propulsor for Underwater Robot
}

\author{
Kyung-Jin Kim*, Doo-Hyoung Lee*, Warn-Gyu Park* and Han-Il Park** \\ *School of Mechanical Engineering, Pusan National University, Busan, Korea \\ **Department of Ocean Engineering, Korea Maritime University, Busan, Korea
}

KEY WORDS: Ducted propulsor 덕트 추진기, Propeller design 프로펠러 설계, Underwater robot 수중로봇, Navier-Stokes equation 나 비아-스톡스 방정식, Hydrodynamic force 수력학적 힘

\begin{abstract}
Underwater robots are generally used for the construction of seabed structures, deep-sea ecosystem research, ocean energy development, etc. A ducted marine propulsor is widely used for the thruster of an underwater robot because of its collision protection, efficiency increase, cavitation reduction, etc. However, the flow of a ducted propeller is very complex because it involves strong flow interactions between the blade impeller and duct. The present work aimed to design a ducted propeller using 2-D strip theory and CFD analysis. The hydrodynamic forces (i.e. and ) were computed to set the local angle of attack in a spanwise direction of the propeller blade. After the propeller design, performance coefficients such as the thrust, torque, and efficiency were computed to check whether the designed performance was achieved. To validate the present analysis, the thrust was compared with experimental data and good agreement was obtained.
\end{abstract}

\section{1. 서 론}

각종 해양자원의 이용 및 개발은 21 세기 고도 산업사회 건설 과 지속적인 경제 발전에 필수적이며, 다양한 해양 공간 이용 및 개발관련 산업으로 발전할 수 있는 무한한 성장가능성을 보유 하고 있다. 이와 같은 해양 산업을 활성화할 수 있는 핵심적인 분야중의 하나가 수중로봇이다. 대부분의 수중로봇은 해저탐사, 해양구조물 보수 및 유지 그리고 해중 촬영과 선저 청소용 등 으로 활용되고 있다. 이러한 수중로봇은 해양자원확보와 해양 개발 등의 기본이 되는 선박의 검사 및 청소뿐만 아니라 해양 관련 기술에 미치는 파급효과가 매우 높다. 또한, 해중에서의 자 원탐사, 수자원 관리 등의 다양한 작업에 인간이 직접 할 수 없는 일들을 수행할 수중 로봇을 포함하는 수중 작업장비의 개발과 수요는 증가추세에 있다. 심해의 광활한 공간에서 작동하게 되 는 수중로봇의 효율적인 작업을 위해서는 수중로봇의 이동, 자 세제어 등을 위한 추진기시스템의 역할이 중요하다. 수중 추진
시스템은 스크류, 구동모터, 모터 드라이버, 컨트롤러 및 방수시 스템으로 구성되며 수중로봇의 성능이나 비용 면에서 매우 큰 비중을 차지하지만 전량 외국에서 수입하고 있는 실정이다. 따 라서, 이들을 시급히 개발하여 사업화 시킬 필요성이 있다.

수중로봇용 추진기로 널리 이용되는 것 중 하나가 덕트 프로 펠러이다. 덕트는 추진효율향상, 프로펠러 보호, 캐비테이션(Cavitation) 감소 등의 많은 장점을 가지지만, 덕트와 프로펠러의 상 호작용으로 인해 그 유동장이 매우 복잡하여 해석하는데 어려움이 있다. 하지만 수력학적 성능 분석을 통한 효율적인 추진기 설계 를 위해서는 정확한 유동해석이 필요하다. Kerwin et al. (1987)은 페널코드를 사용하여 덕트 추진기의 유동을 해석하였다. Jung (2002), Jang et al.(2004), Park et al.(2005a)은 슬라이당 멀티블럭 기법을 적용하여 로터와 스테이터의 상호작용이 있는 덕트 추 진기를 해석하였고, Jung et al.(2001), Park et al.(2005b)은 로터와 스테이터의 상호작용이 있는 워터젯의 유동을 해석하였다. Joung et al.(2009)는 전산해석을 이용하여 덕트형 잠수정의 운동해석

\section{Received 12 October 2012, revised 15 November 2012, accepted 11 December 2012}

Corresponding author Warn-Gyu Park : +82-51-510-2457, wgpark@pusan.ac.kr

(c) 2012, The Korean Society of Ocean Engineers

It is noted that this paper is revised edition based on proceedings of KSOE 2010 in Mokpo. 
을 하였으며, Lee et al.(2011)은 상용 추진기를 사용하는 잠수정 의 추진성능을 해석하였다.

본 연구에서는 익형해석을 바탕으로 2-D(Dimension) 스트립(Strip) 이론을 적용하여 수중로봇용 추진시스템을 설계하고, $\mathrm{CFD}(\mathrm{Com}-$ putational fluid dynamics) 상용코드를 이용하여 설계된 덕트 추진기의 난류 유동장을 해석 하고 그 수력학적 성능을 분석 하고자 한다.

\section{2. 덕트 추진기의 설계}

\section{1 프로펠러 설계 과정}

프로펠러의 블레이드는 통상 각 반경위치에서 단면 익형들의 집합으로 표현된다. 즉, 2차원 익형을 실린더 곡면 상에 나타내 고, 각 반경의 단면 익형들을 반경방향으로 쌓아서 프로펠러의 형 상을 표현한다. 따라서 프로펠러를 구성하고 있는 단면익형들 의 국부적인 받음각은 프로펠러 성능에 큰 영향을 미친다. 본 연 구에서는 익형의 유동해석을 통해 효율적인 받음각을 선정하여 각 단면을 배치하는 방법으로 프로펠러를 설계하였다.

Fig. 1에 본 연구에서 진행된 프로펠러 블레이드 설계 과정을 도식화 하여 나타내었다. 2-D 익형 유동 해석을 바탕으로 익형 의 유동 특성을 파악하고 효율적인 받음각을 선정한 다음, 2-D 스 트립이론을 적용하여 프로펠러를 설계하였다. 설계된 추진기 프로펠러 외부에 덕트를 추가하여 덕트 프로펠러를 구성한 후, 추진기의 성능 분석을 위해 3-D 유동해석을 진행하였다. 유동 해석의 검증을 위해 실험 데이터와 비교하였다.

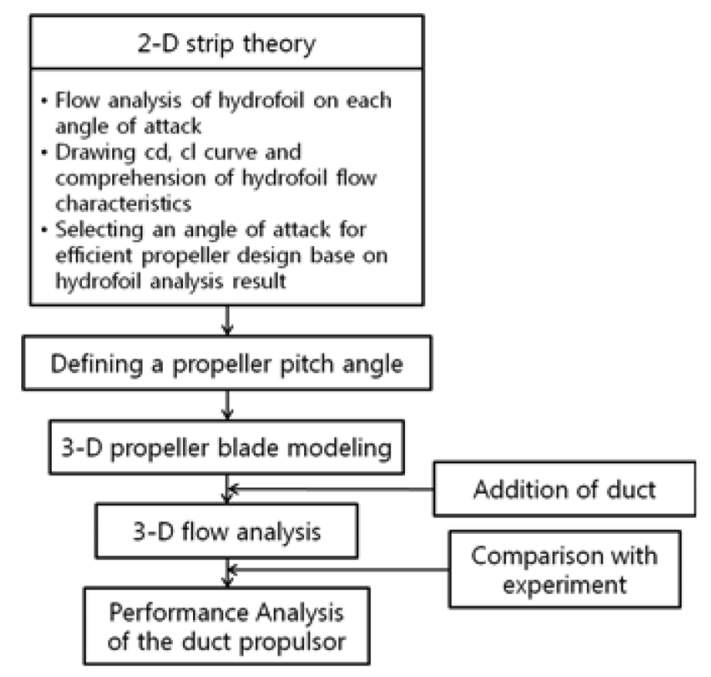

Fig. 1 Process of propulsor design

\section{2 익형의 형상 및 격자생성}

Fig. 2(a)는 설계에 사용된 익형의 좌표를 Fig. 2(b)는 익형의 형상을 나타낸 그림이다. 익형을 2-D 스트립이론을 이용하여 프로펠 러를 설계하기위해 익형의 유동특성 파악하고자 각 받음각별 유동 해석을 실시하였다. 일반적인 선박용 프로펠러와 달리 역회전이 많은 수중로봇용 프로펠러의 특성을 고려하여 익형의 유동해석도 정 회전과 역회전의 두 경우를 해석하여 설계에 반영하였다. 2 차원
유동 해석을 위한 격자는 Fig. 3에 나타내었다. 경계층 내의 벽 면의 영향이 정확히 표현 될 수 있도록 Fig. 3(b), (c)와 같이 벽면 주위에 정렬격자를 조밀하게 생성하였으며 비정렬 격자를 이용 하여 연결 하였다. 전체 격자수는 $4.8 \times 10^{4}$ 개로 구성되어 있다.

\begin{tabular}{ccccccc}
\hline \hline$X$ & $Y_{\text {upper }}$ & $Y_{\text {lower }}$ & & $X$ & $Y_{\text {upper }}$ & $Y_{\text {lower }}$ \\
\cline { 1 - 4 } \cline { 5 - 7 } & 0 & 0 & & 0.6 & 0.0547 & -0.0185 \\
0.001 & 0.0065 & -0.0065 & & 0.7 & 0.0469 & -0.0171 \\
0.005 & 0.0138 & -0.0138 & & 0.8 & 0.0374 & -0.0150 \\
0.01 & 0.0182 & -0.0182 & & 0.85 & 0.0317 & -0.0140 \\
0.03 & 0.0264 & -0.0226 & & 0.9 & 0.0252 & -0.0130 \\
0.05 & 0.0336 & -0.0240 & & 0.95 & 0.0179 & -0.0122 \\
0.075 & 0.0418 & -0.0248 & & 0.97 & 0.0148 & -0.0119 \\
0.1 & 0.0489 & -0.0254 & & 0.98 & 0.0132 & -0.0118 \\
0.2 & 0.0671 & -0.0252 & & 0.99 & 0.0116 & -0.0116 \\
0.3 & 0.0717 & -0.0225 & & 0.995 & 0.0096 & -0.0096 \\
0.4 & 0.0683 & -0.0200 & & 0.999 & 0.0047 & -0.0047 \\
0.5 & 0.0618 & -0.0190 & & 1 & 0 & 0 \\
\hline
\end{tabular}

(a) The coordinates of hydrofoil

(b) Cross-sectional shape of 2-D hydrofoil

Fig. 2 The geometry of hydrofoil

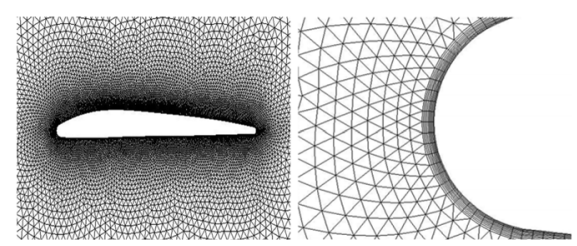

(a) Configuration of (b) Nodes near grid

leading edge

Fig. 3 Grid system of 2-D hydrofoil

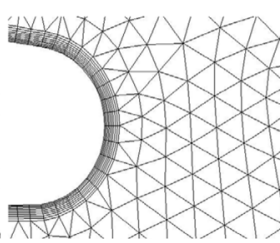

(c) Nodes near trailing edge

\section{3 정방향 회전시 익형의 유동해석결과}

Fig. 4는 프로펠러가 정방향으로 회전할 경우에 익형의 받음 각별 유동장의 모습과 표면 압력계수를 나타낸 그림이다. 받음 각 $\alpha=16^{\circ}$ 이하에서는 그림과 같이 유체가 익형의 표면을 따 라 흐르지만, 받음각 $\alpha=20^{\circ}$ 이상에서는 익형의 상부면을 따라 심한 박리현상이 생겨 실속현상이 나타남을 알수 있다. Fig. 4 (2)의 표면 압력계수 곡선은 익형의 상부면과 하부면의 압력차 이를 나타내는 것으로, 표면 압력계수 곡선의 내부면적은 각 단 면에서의 양력 성분을 나타낸다.

Fig. 5는 익형의 받음각별 해석결과를 바탕으로 받음각 변화에 따른 항력 $\left(C_{D}\right)$ 및 양력계수 $\left(C_{L}\right)$ 곡선을 나타낸 그림으로, 정회전의 경우 $\alpha=16^{\circ}$ 부근에서 양력계수는 감소하는 것은 실속현상이 발생하였기 때문이다. 각 계수들은 식(1) (2)로 표현된다.

$$
\begin{aligned}
& C_{D}=\frac{D}{\frac{1}{2} \rho V_{\infty}^{2} A} \\
& C_{L}=\frac{L}{\frac{1}{2} \rho V_{\infty}^{2} A}
\end{aligned}
$$




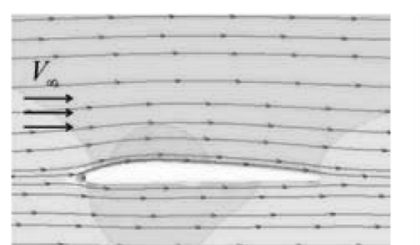

(a) $\alpha=0^{\circ}$
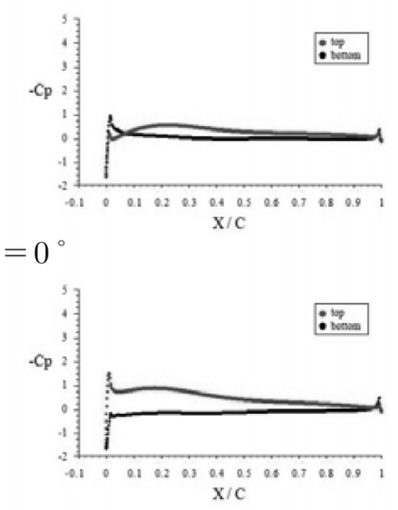

(b) $\alpha=4$

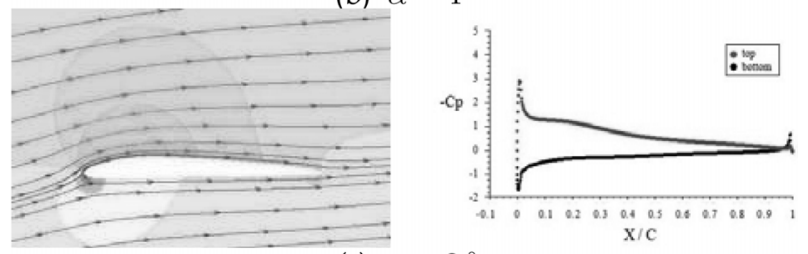

(c) $\alpha=8^{\circ}$
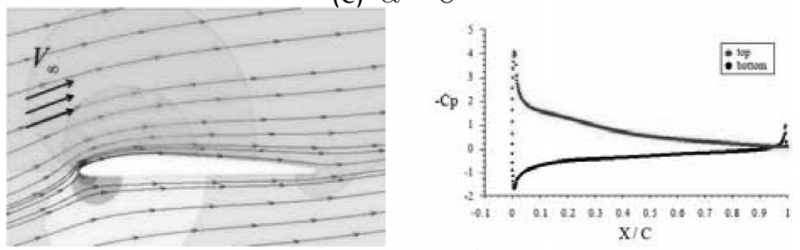

(d) $\alpha=12^{\circ}$

( 1 ) Pressure contour

( 2 ) Pressure coefficient
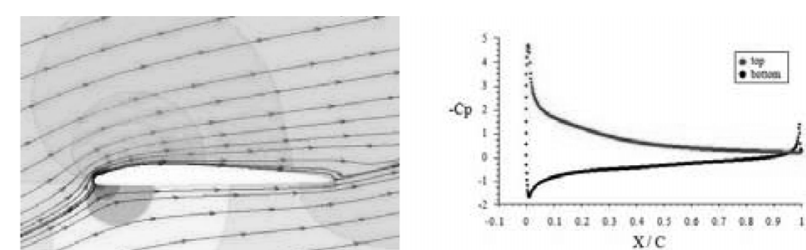

(e) $\alpha=16^{\circ}$
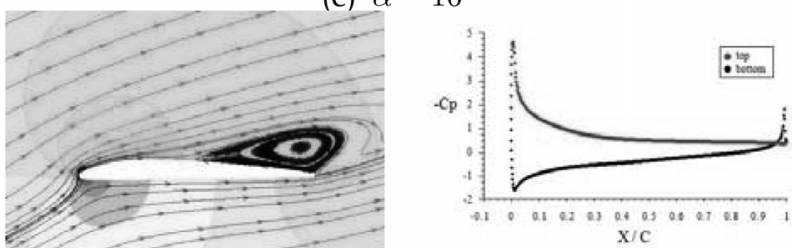

(f) $\alpha=20^{\circ}$
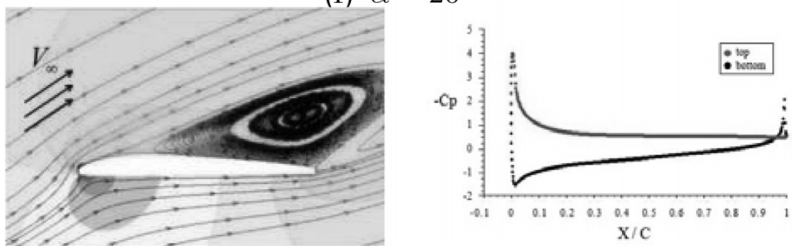

(g) $\alpha=24^{\circ}$
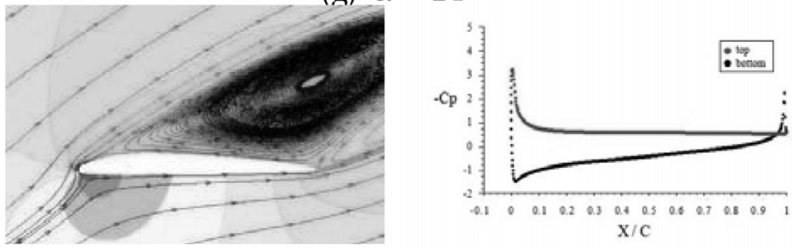

(h) $\alpha=28$

(1) Pressure contour

( 2 ) Pressure coefficient

Fig. 4 Flow filed and $C_{p}$-distribution of the hydrofoil in the case of normal rotation

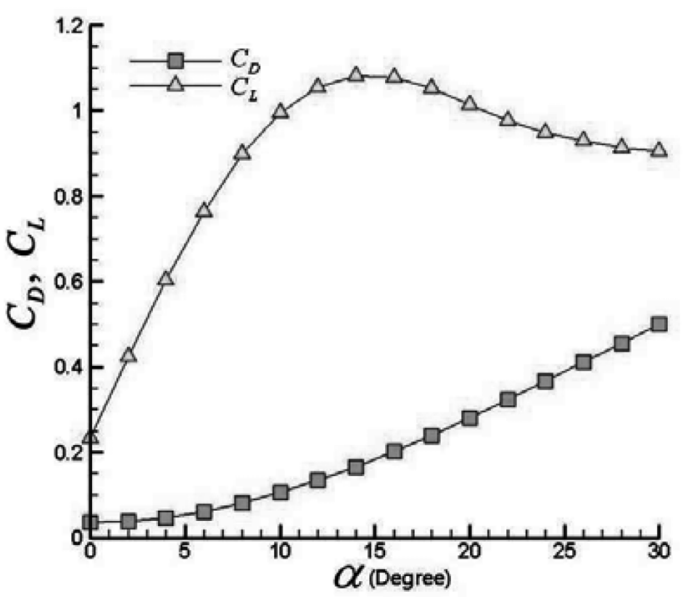

Fig. 5 Lift and drag coefficient of the hydrofoil in the case of normal rotation

여기서 $D$ 는 익형의 항력, $L$ 은 양력, $V_{\infty}$ 은 유체의 유입속도 이다.

\section{4 역방향 회전시 익형의 유동해석결과}

Fig. 6은 프로펠러가 역방향으로 회전할 경우에 익형의 받음 각별 유동장과 표면 압력계수를 나타낸 모습으로, 역회전 시에 는 정회전에 비해 작은 받음각인 $\alpha=16^{\circ}$ 에서 유동박리가 발
생하였다. 표면 압력계수 곡선을 보면 받음각 $\alpha=4^{\circ}$ 이하에서 는 익형 하부면의 압력이 상부면의 압력보다 낮게 나타났으며, 이에 따라 양력이 음의 값을 가짐을 알 수 있다. 또한 익형의 뒷날(Trailing edge) 부근은 익형의 형상으로 인해 받음각에 관 계없이 하부면의 압력이 상부면 보다 낮은 압력을 나타내었다. Fig. 7은 역뱡향 회전시 항력 및 양력계수 곡선을 나타낸 모습 으로, 전반적으로 정회전에 비해 작은 양력계수 값을 나타냈으 며, 받음각 $\alpha=4^{\circ}$ 이하에서는 익형의 형상에 의해 양력계수가 음의 값을 나타내었다.

\section{5 프로펠러 블레이드 설계}

Fig. 8은 2차원 스트립이론을 적용하여 설계한 프로펠러의 각 단면의 분포모습을 나타낸 그림으로 Fig. 5와 Fig. 7의 해석결과 를 바탕으로 각 단면의 받음각이 $12^{\circ}$ 가 되도록 각 단면의 익형을 배치하여 프로펠러를 설계하였다. 프로펠러의 단면별 피치각은 Table 1에 나타나 있다. 프로펠러의 직경은 $170 \mathrm{~mm}$, 허브의 직 경은 $70 \mathrm{~mm}$, 날개 수는 7 개이며, 프로펠러의 외부에 덕트를 추 가하였다. 덕트의 단면의 좌표와 형상은 Fig. 9에 나타나 있다, 덕트 익형은 추진기 작동 시 유입되는 유체의 유동을 고려하여 받음각을 $3.3^{\circ}$ 로 설계하였으며, 회전축에서부터 앞날(Leading edge)까지의 거리는 $0.57 D$ 로 설계하였다. Fig. 10은 설계된 덕 트 추진기의 모습이다. 

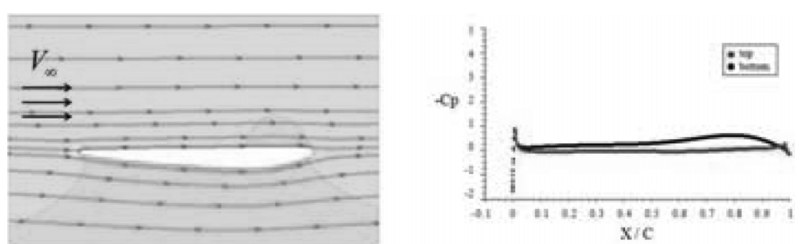

(a) $\alpha=0^{\circ}$
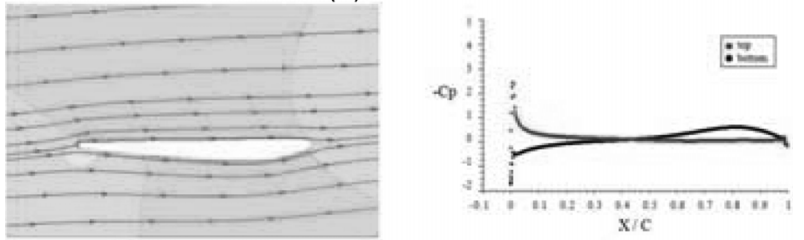

(b) $\alpha=4$
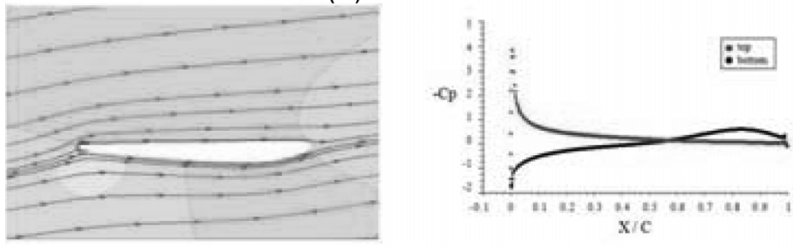

(c) $\alpha=8$
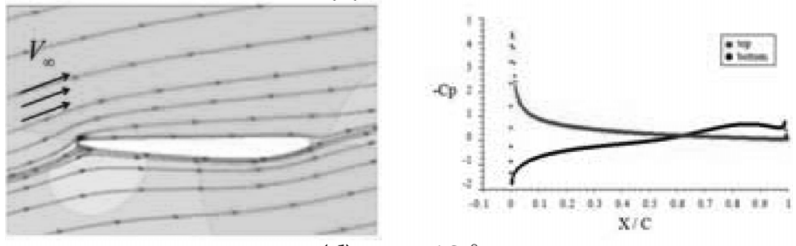

(d) $\alpha=12$

(1) Pressure contour

( 2 ) Pressure coefficient
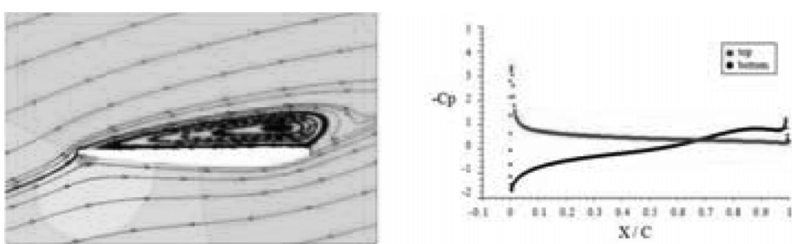

(e) $\alpha=16^{\circ}$
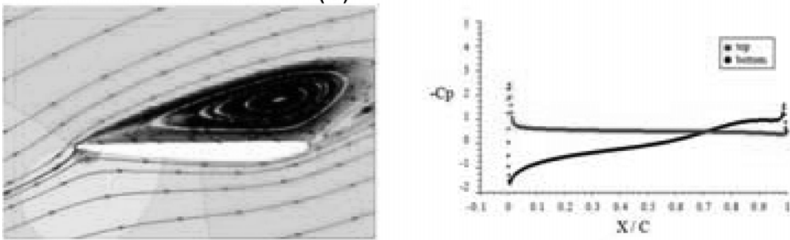

(f) $\alpha=20^{\circ}$
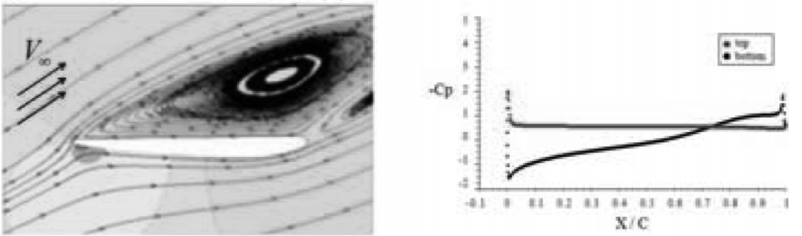

(g) $\alpha=24^{\circ}$
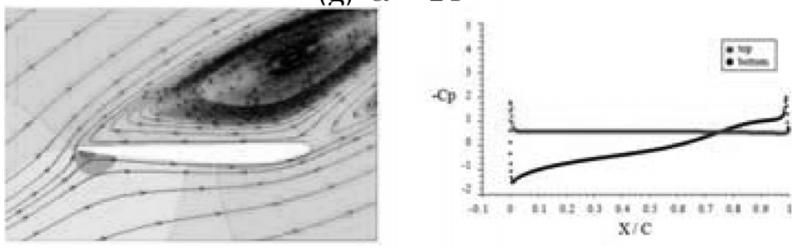

(h) $\alpha=28^{\circ}$

( 1 ) Pressure contour

( 2 ) Pressure coefficient

Fig. 6 Flow filed and $C_{p}$-distribution of the hydrofoil the case of reverse rotation

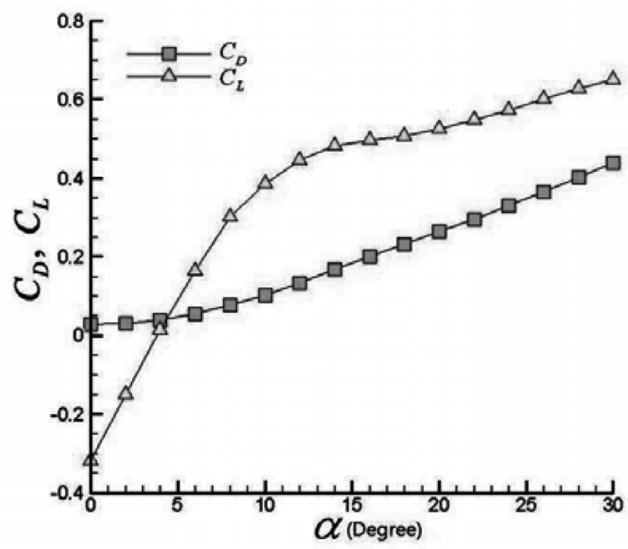

Fig. 7 Lift and drag coefficient of the hydrofoil in the case of reverse rotation

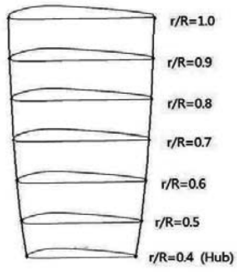

(a) Planform shape

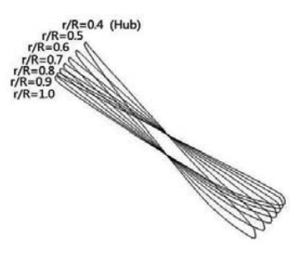

(b) Stack-up of the blade strip Fig. 8 Blade element profiles along spanwise direction
Table 1 Sectional pitch angle and Local angle of attack of a ducted propulsor

\begin{tabular}{|c|c|c|}
\hline$r / R[\%]$ & Pitch angle [degree] & Local angle of attack [degree] \\
\hline 100 & 29.1 & 12 \\
\hline 90 & 30.8 & 12 \\
\hline 80 & 33.0 & 12 \\
\hline 70 & 35.7 & 12 \\
\hline 60 & 39.1 & 12 \\
\hline 50 & 43.6 & 12 \\
\hline $40(\mathrm{Hub})$ & 48.7 & 12 \\
\hline
\end{tabular}

\begin{tabular}{ccccccc}
\hline \hline$X$ & $Y_{\text {upper }}$ & $Y_{\text {lower }}$ & & $X$ & $Y_{\text {upper }}$ & $Y_{\text {lower }}$ \\
\cline { 1 - 4 } \cline { 5 - 6 }$n$ & 0 & 0 & & 0.6 & 0.0217 & -0.0628 \\
0.001 & 0.0099 & -0.0174 & & 0.7 & 0.0174 & -0.0483 \\
0.005 & 0.0189 & -0.0435 & & 0.8 & 0.0132 & -0.0338 \\
0.01 & 0.0249 & -0.0574 & & 0.85 & 0.0111 & -0.0265 \\
0.03 & 0.0333 & -0.0873 & & 0.9 & 0.0090 & -0.0193 \\
0.05 & 0.0344 & -0.1037 & & 0.95 & 0.0069 & -0.0121 \\
0.075 & 0.0359 & -0.1152 & & 0.97 & 0.0603 & -0.0092 \\
0.1 & 0.0373 & -0.1197 & & 0.98 & 0.0056 & -0.0077 \\
0.2 & 0.0386 & -0.1147 & & 0.99 & 0.0052 & -0.0063 \\
0.3 & 0.0344 & -0.1062 & & 0.995 & 0.0050 & -0.0055 \\
0.4 & 0.0301 & -0.0917 & & 0.999 & 0.0028 & -0.0034 \\
0.5 & 0.0259 & -0.0772 & 1 & 0 & 0 \\
\hline
\end{tabular}

(a) The coordinates of duct section

Fig. 9 The geometry of duct (continued) 
(b) Cross-sectional shape of duct

Fig. 9 The geometry of duct

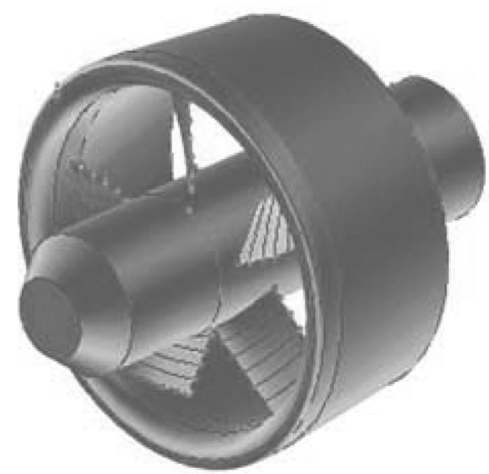

Fig. 10 Configuration of the ducted propulsor

\section{3. 추진기 유동 해석}

\section{1 추진기 격자생성 및 경계조건}

설계된 추진기의 성능을 평가하기 위해 전산유동해석을 진행 하였다. 해석은 CFD 상용코드인 Fluent 6.3(Fluent 6.3 user's guide) 을 이용하여 수행하였다.

격자의 형상은 Fig. 11 과 같이 전체 해석영역을 비정렬 격자를 이용하여 격자를 생성하였다. 속도 및 압력구배가 큰 덕트 프로 펠러의 끝단에 격자를 집중 시켰으며 표면에서 난류계산을 위

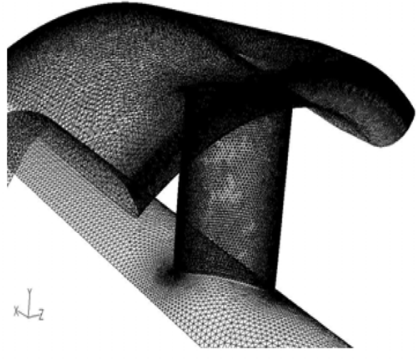

(a) Ducted propulsor

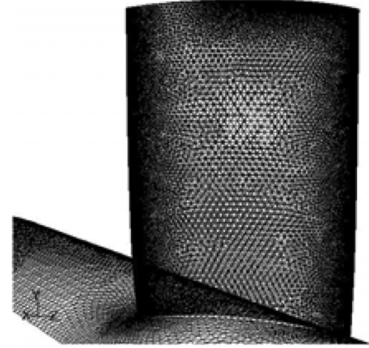

(b) Propeller
Fig. 11 Grid system of the ducted propulsor

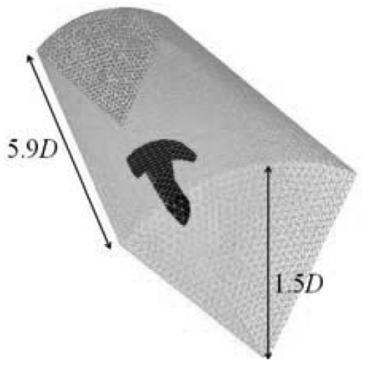

(a) Computational domain

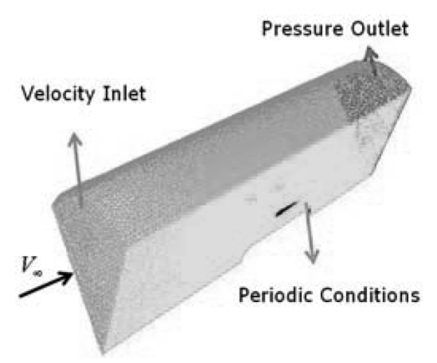

(b) Boundary condition
Fig. 12 Computational domain and boundary condition
하여 프리즘 메쉬를 이용하여 추진기 표면에 5 개의 층을 생성 하였다. 격자수는 비정렬 격자 $3.3 \times 10^{6}$ 개로 구성하였다.

Fig. 12는 추진기 주위의 유동을 해석하기 위한 해석 영역과 경계조건을 나타낸 그림이다. 추진기를 둘러싼 경계(Boundary) 는 회전축으로부터 $1.5 \mathrm{D}$ 의 거리를 가진다. 입구는 주요 해중 작 업장비의 사양인 $3 \mathrm{knots}(1.54 \mathrm{~m} / \mathrm{s})$ 를 경계조건으로 설정하였고, 덕트 프로펠러의 회전속도는 400 1750 rpm 범위에서 7개의 경 우에 대해 계산하였다. 출구는 $p=p_{\infty}$ 로 설정하였다. 격자수를 줄여 계산시간을 단축시키기 위해 주기(Periodic) 경계 조건을 사용하였으며 난류모델은 Standard $k-\epsilon$ model을 사용하였다.

\section{2 추진기 유동 해석결과}

Fig. 13은 $1250 \mathrm{rpm}$ 일 때 설계된 추진기 프로펠러 각 단면의 압력장을 나타낸 모습이다. 반경이 증가할수록 각 단면의 회전 속도가 더 커지게 되므로, 압력구배가 점점 커졌으며 흡입면과 압력면의 압력차이가 더 커짐을 볼 수 있다. Fig. 14은 1250rpm 에서 설계된 추진기의 압력장을 나타낸다. 그림에서 나타난 흡 입면과 압력면의 압력차이가 덕트 프로펠러의 추력으로 나타나 게 된다. Fig. 15은 프로펠러주위의 유선을 나타낸 것으로, 후류의 속도 성분에서 매우 강한 회전성분이 남아있음을 볼 수 있다. Fig.

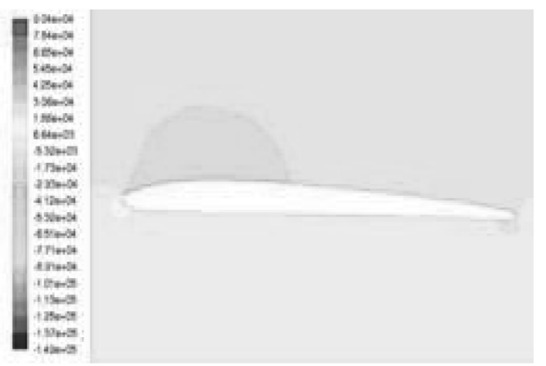

(a) $r / R=0.5$

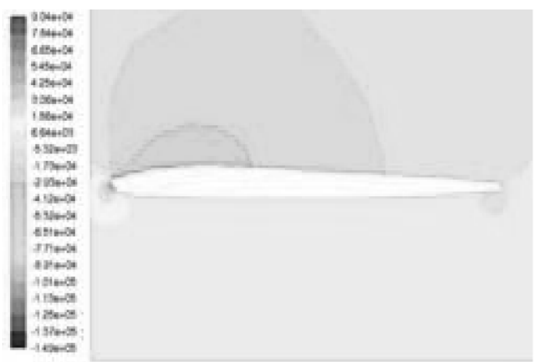

(b) $r / R=0.5$

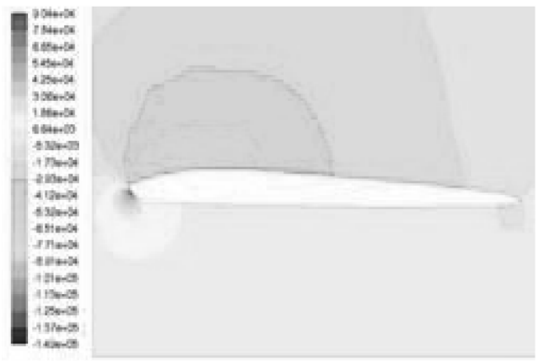

(c) $r / R=0.5$

Fig. 13 Sectional pressure contours of the ducted propulsor at 1250rpm 

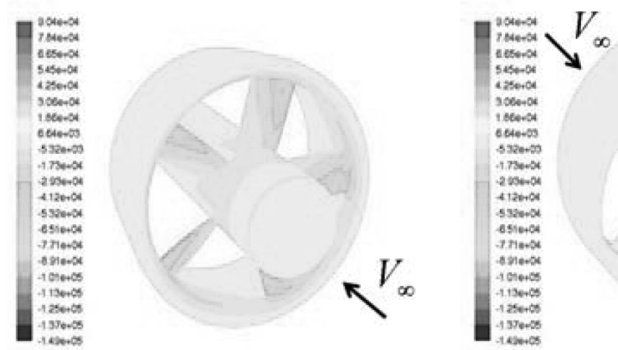

(a) Suction side of propulsor (b) Pressure side of propulsor

Fig. 14 Pressure contours of the ducted propulsor at 1250rpm

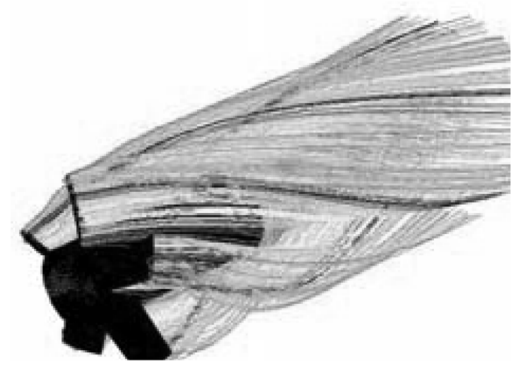

(a) Front

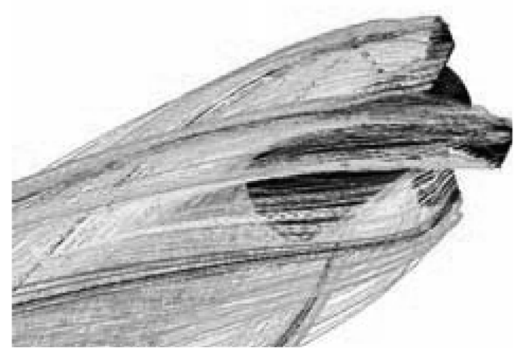

(b) Rear

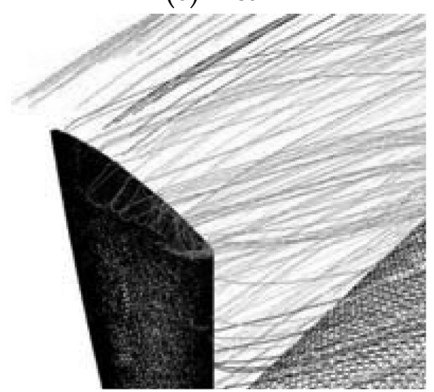

(c) Tip vortex

Fig. 15 Streamlines around the ducted propulsor

15(c)에는 프로펠러의 흡입면과 압력면의 압력 차이로 발생하는 끝단와류(Tip vortex)가 잘 나타나있다.

Fig. 16은 해석결과를 바탕으로 덕트 프로펠러의 전진비 $(J)$ 에 따른 추력계수 $\left(K_{T}\right)$, 토크계수 $\left(K_{Q}\right)$ 그리고 효율 $\left(\eta_{o}\right)$ 을 나타낸 그 림으로, 각 계수들은 식 (3) (6)로 표현된다.

$$
\begin{gathered}
K_{T}=\frac{T}{\rho n^{2} D^{4}} \\
K_{Q}=\frac{Q}{\rho n^{2} D^{5}}
\end{gathered}
$$

$$
\begin{aligned}
& \eta_{o}=\frac{K_{T}}{K_{Q}} \cdot \frac{J}{2 \pi} \\
& J=\frac{V_{\infty}}{n D}
\end{aligned}
$$

여기서 $\mathrm{T}$ 는 덕트 프로펠러의 추력을 $\mathrm{Q}$ 는 프로펠러의 토크, $\mathrm{n}$ 은 프로펠러의 회전수(rps) 를 나타낸다. 전진비가 증가할수록 추력계수와 토크계수는 감소하고, 효율은 전진비 1.0 을 정점으 로 증가하다 감소하는 경향을 보였다.

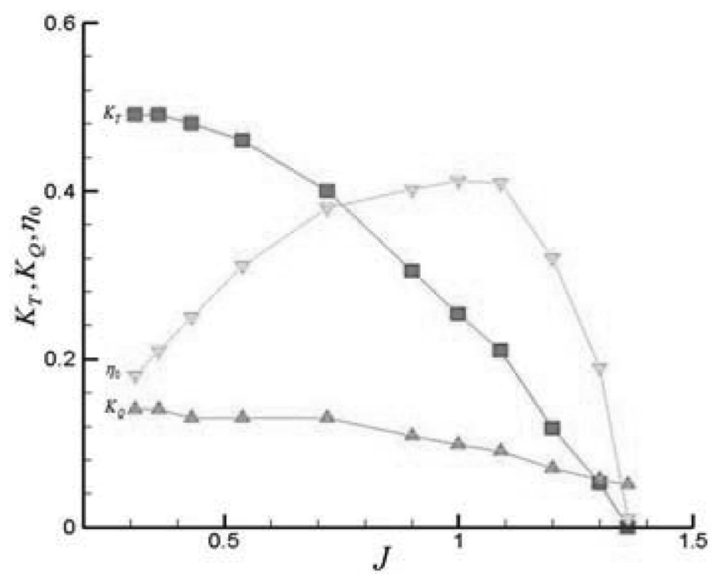

Fig. 16 Performance of the ducted propulsor
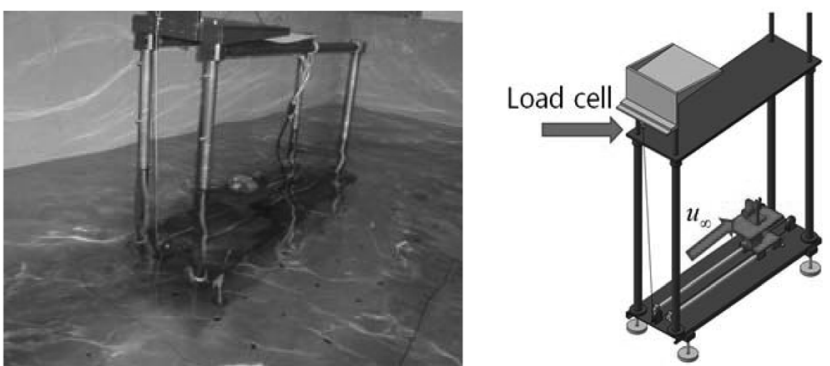

(a) Configuration of experimental

(b) Method of measurement apparatus

Fig. 17 Configuration of experimental apparatus for measuring thrust

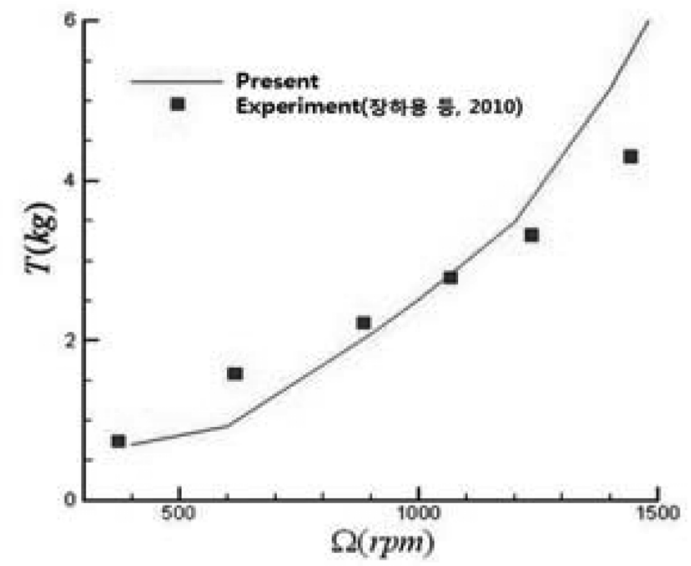

Fig. 18 Comparison of thrust with experiment 


\section{3 전산해석 결과와 실험결과 비교 분석}

해석의 검증을 위해 소형 덕트 추진기의 추력시험 데이터 (Jang et al., 2010)를 해석결과와 비교하였다. Fig. 17은 제작된 추진기의 추력측정을 위한 실험장치의 모습이다. 실험조건은 수 조에서 전진비가 0 일 때, 6 가지 경우의 $\mathrm{rpm}$ 에 대하여 각각의 추력 을 측정하였다. 측정된 추진기의 추력은 Fig. 18에 회전수를 400 $1500 \mathrm{rpm}$ 으로 바꾸어 가며 해석한 결과와 비교하여 나타내었다. 실험값과 해석값을 비교 하였을 때, 계산된 추력은 실험값과 비 교적 일치하였다.

\section{4. 결 론}

본 연구는 수중로봇용 추진기 개발을 위해 수중로봇 추진기 용 프로펠러를 설계 하였고, 설계된 추진기의 수력학적 성능확 인을 위해 CFD 상용코드를 이용하여 추진기의 유동해석 및 성 능분석을 진행하였다.

1) 추진기 프로펠러의 설계를 위해 2차원 익형을 해석하고 각 받 음각에 대해 $C_{D}$ 및 $C_{L}$ 곡선을 도출하여 유동 특성을 파악하였다.

2) 익형 해석을 바탕으로 효과적인 받음각을 선정하여 2차원 스트립이론을 적용하여 추진기용 프로펠러를 설계하였다.

3) 설계한 추진기의 성능을 확인하기 위하여 추진기의 유동해석 및 성능분석을 하였다. 해석의 검증을 위해서 소형 추진기의 유 동해석을 진행하여 추력 실험결과와 비교하였으며, 실험값과 비교적 일치함을 확인할 수 있었다.

본 논문은 수중로봇개발을 위한 연구과제로서 전산유동해석을 통해 보다 효율적인 추진기 설계를 목적으로 하였으며, 본 논문의 연구내용은 향후 프로펠러 연구의 참고자료로 활용될 수 있을 것이다.

\section{후기}

본 연구는 2011년도 지식경제부의 재원으로 한국에너지 기술 평가원(KETEP)의 지원을 받아 수행한 연구 과제입니다.

(No. 20114010203080)

\section{참 고 문 헌}

Jang, H.Y., Yang, A.Y., So, M.O., Park, H.I., 2010. Development of Underwater Thrusting System Driven by BLCD Motor. Proceedings of the Korean Society of Ocean Engineers 2010 Fall Annual Conference, Mokpo Korea, 41-45.

Jang, J.H., Jung, Y.R., Park, W.G., 2004. Propulsive performance analysis of ducted marine propulsors with rotor- stator interaction, Journalof Shipand Ocean Technology, 8(1), 31-41.

Joung, T.H., Sammut, K., He, F., Lee, S.K., 2009. A Study on the Motion Analysis and Design Optimization of Ducted Type AUV(Autonomous Underwater Vehicle) by Using CFD(Computational Fluid Dynamics) Analysis. Journal of the Korean Society of Ocean Engineers, 23(1), 48-53.

Jung, Y.R., 2002. A Study on the Flow Characteristics of a Marine Propulsor with Variation of Tip Clearances Including Rotor-Stator Interaction. Doctoral Dissertation, Pusan National University.

Jung, Y.R., Park, W.G., Jun, J.G., Lee, S.W., Lee, K.C., 2001. Numerical Flow Analysis of a Single-Stage Ducted Marine Propulsor. 7th International Congresson Fluid Dynamicsand Propulsion, SHARM-EL-SHEIKH, SINAI, EGYP.

Kerwin, J.E., Kinnas, S.A., Lee, J.T., Shih, W.Z., 1987. A surface panel method for the hydrodynamic analysis of ducted propellers. Transactions of SNAME, 1987-1995.

Lee, J.M., Choi, H.T., Kim, K.H., Yeo, D.J., Lee, P.M., 2011. The Estimation of the Propulsion of a UUV Using Commercial Thruster. Journal of the Korean Society of Ocean Engineers, 25(1), 27-31.

Park, W.G., Jang, J.H., Chun, H.H., Kim, M.C., 2005a. Numerical Flow and Performance Analysis of Waterjet Propulsion System. Ocean Engineering, 32, Issues 14-15, 1740-176.

Park, W.G., Jung, Y.R., Kim, C.K., 2005b. Numerical Flow Analysis of Single-Stage Ducted Marine Propeller, Ocean Engineering, 32, 1260-1277. 